\title{
6 My Buddha-nature and my Christ-nature
}

\author{
Paul Knitter
}

Although any statement that is supposed to apply to all religions is risky, I do believe that a case can be made that all wisdom traditions recognize, in one form or another, that religions really don't know what they are talking about! All of them insist that what they are seeking or what they believe they have come to experience, what many of them call ultimate reality, is beyond all human comprehension. No human being, and no human community of spiritual seekers, can grasp the fullness of God, or Tao, or Brahman, or Wakan Tanka. As a tee-shirt that someone gave me - and which would make an ideal gift for all theologians - puts it: "God is too big to fit into any one religion."

In my theology classes, I have used the image of ultimate reality or Truth as a universe surrounding us that, in its vastness and richness, is beyond all human sight. To see it, we need telescopes. But all such telescopes - in their varying power and specializations - do two things: they enable us to see more of the Truth that otherwise would be beyond our visual capacity; but they also limit what we can see, for focusing on one part of the universe of truth leaves out others. So in order to see more of the universe than what my telescope allows me to see, I need to look through other telescopes that are different in their abilities and specificities than mine.

The analogy is clear. If followers of the different wisdom traditions are convinced that they have encountered and come to know a Truth that has given meaning to their lives, they also know that there is more to the Truth than what they know. They know, but they also know that they don't know. What more and more followers of the religions are coming to realize in our interconnected, intercommunicating contemporary world is that they can discover and come to know more of the Sacred by using, as it were, the telescopes of other religions. In order to learn more of the Sacred, in order to overcome the limitations of one's own religion, one must engage the teachings and practices of other religious paths. As Raimon Panikkar put it with his typical edgy insightfulness: "To answer the question "Who/what is my God,' I have to ask the question 'Who/what is your God' " (Panikkar 1979, 203). 
That is a question posed in interreligious dialogue. To be authentic, dialogue requires much more than "tolerant conversation" in which participants are "nice" to each other. It is also more than a sincere conversation in which all parties seek to learn more about each other. Anyone who truly commits herself to real dialogue commits herself to the possibility and to the expectation of learning from the other. And insofar as one learns something new or different from another, one is also learning something new about oneself. The goal is not just information but also transformation. One might have to change not only one's ideas but also one's religious identity, one's way of being religious.

I'm going to write out of my own personal search for a spirituality that can be experientially meaningful, intellectually coherent, and ethically responsible. My reflections as a theologian will, in other words, be based on my spiritual practices and experience. I hope that these reflections will be an example of theology as "fides quaerens intellectum" - spiritual experience trying to make sense of itself. I will be following the age-old Christian directive that the "lex credendi" (how we believe) should flow from the "lex orandi" (how we pray). Doctrine should be grounded in and tested by spirituality.

I will begin with some of the difficulties or stumbling blocks that I and from my experience as a teacher and a preacher - many Christians have with what they have been told to believe about Jesus the Christ. If Christians no longer believe that "outside the church there is no salvation," many now struggle with the related claim "outside of Jesus there is no salvation."

Many Christians sense a discomforting ambiguity when they ask themselves: "Just how does Jesus save me? How is he my savior?" There is increasing dissatisfaction with the atonement theory - that Jesus's death somehow paid the price that satisfied God's wrath or demand for justice after the "original sin."

But what is to take the place of atonement? I want to suggest that our conversation with Buddhism can provide some very welcome help.

I will be using the notion of "functional analogy" as it is developed by my co-author, Roger Haight, in our recent book Jesus and Buddha: Friends in Conversation (Haight and Knitter 2015). Functional analogies between two differing traditions would be those teachings or symbols that, despite their profound differences, serve similar purposes or respond to similar concerns and thus can offer possibilities of comparison that illumine and enrich each other.

The Tibetan Buddhist practice from which I would like to suggest some functional analogies with the saving role of Jesus is that of Guru Yoga, particularly as taught by my teacher, Lama John Makransky, as "benefactor practice." ${ }^{1}$ Tibetan teachers recognize the need for embodiments or visual representations of the ultimate reality that is beyond conceptual comprehension. These are our "spiritual benefactors," who have embodied and so can reveal the nature of mind. For Buddhists, of course, the primary spiritual 
benefactor will be Buddha, or Tara, or one of the vast team of bodhisattvas. Makransky encourages Christians to welcome Jesus, as well as Mary, as their spiritual benefactors.

Crucial for this practice is to visualize and truly feel the presence of the spiritual benefactor. Visualizations of the benefactor are intense, particular, contextual, and set in the vivid colors of what St. Ignatius in the Jesuit Spiritual Exercises might call the "compositio loci." The practitioner is encouraged to feel the energy of the benefactor's love that embraces and holds her fully and penetrates, as Makransky puts it, into every cell of one's body. After having received the love of the benefactor into one's total being, the practitioner, in the second step of this practice, extends the love to all sentient beings.

The final phase is to let the images of the benefactor dissolve and allow oneself to merge nonconceptually into the Essence Love that was manifest and communicated through the benefactor. This is the "nonconceptual" goal of the practice. We grow in awareness that there is a nondual oneness between the spiritual benefactor and ourselves and also between the teacher and student, between benefactor and recipient, between savior and saved, within the vast cognizant, compassionate space that contains and animates us all.

When Christians visualize Jesus as their spiritual benefactor, they can discover deeper ways of understanding and experiencing Jesus. Seventy times St. Paul uses the phrase "en Christo einei" - to be in Christ Jesus. The Buddhist benefactor practice functions analogously for the Christian as a way of waking up to what it means or how it feels "to be in Christ Jesus," or to "put on the mind of Christ" (Phil 2:5), or to be the body of Christ (I Cor 12:27). Having gone through the visualization of Christ, having received of the love of Christ, having extended that love to all the others that make up his body, and finally having let the image go in order to fuse into the mystery of the risen Christ-Spirit, the Christian can pronounce, with clarity, "It is now no longer I who lives; it is Christ living in/as me" (Gal 2:20).

This is salvation - not as an atoning process that takes place outside of oneself but as a transformative unitive experience. Jesus saves in essentially the same way that the transcendent Buddha saves: not by constituting the nature of mind or God's saving love, but by revealing and so making it effectively present. With Christ, one is a recipient and a conduit of the Essence Love that Jesus called Abba. To be saved, therefore, is the nondual experience of being in Christ Jesus. In this experience, Jesus certainly plays a very unique role. But it is a uniqueness that is, by its very nature, larger than Jesus and so shareable with other unique embodiments of Essence Love or Spirit.

In another functional analogy, both Buddha and Jesus can be considered "liberators" - as bearers of a message that can enable humans to achieve the well-being of what Buddha called enlightenment and of what Jesus called the Reign of God. They shared a common starting point for their 
preaching: the sufferings that all humans (though some more than others) have to face: the inadequacies, the perplexities, the insufficiencies, the diminishments, the pains and disappointments that darken human existence. Both teachers began their missions out of a concern for the sufferings of their fellow human beings.

As indicated in the Second of the Four Noble Truths, for Buddhists, the fundamental cause of suffering is found in the tanha, or self-centered greed, that all humans have to deal with. This selfishness is caused by the ignorance that human beings are born into. Hence, the importance of enlightening, or transforming our sense of who and what we are. What we really are, according to the teachings of the Dharma, is anatta - not-selves - beings who exist as interbeings with others. Our own well-being consists in fostering the well-being of others. Enlightenment is to wake up to that truth, that reality.

At this point, liberationist Christians will remind Buddhists that the results of ignorance go beyond the individual. The actions that follow upon my lack of awareness of my nature as anattalnot-self are not only my actions; they become, slowly but inevitably, society's actions. My own ego-centered attitudes and acts become embodied in social forms; they incarnate themselves, as it were, in the way society works. If Buddhists understand karma to be the unavoidable results that follow every action or choice we make, Christians will point out that individual karma becomes social karma.

Sinful or greedy structures remain even after individuals have been enlightened. Liberationist Christians insist on the reality of social sin, which can remain even after individual sin has been removed. To transform the structures of one's awareness and thinking does not necessarily change the structures of society. One can be enlightened and full of compassion for all sentient beings without realizing that one remains a part of an economic system that continues to cause suffering to others.

So Christians remind Buddhists that transforming oneself is different from - and should not become a substitute for - transforming society. This implies that compassion, though necessary, is insufficient. Justice is also necessary. If compassion calls us to feed the hungry, justice urges us to ask why they are hungry. Mindfulness is necessary for living a life of inner peace, but we also need social mindfulness of how our reified, ego-centric thoughts and fears become reified social or political systems.

If Buddhists are to effectively extend their practice of personal mindfulness to include social mindfulness, they will also have to take seriously the Christian liberationists' call for a "preferential option for the oppressed." This preference calls upon all spiritual seekers to be sure that their quest includes, as an integral element, the effort to become aware of the experience of those who have been pushed aside, those who don't have a meaningful voice in the decisions of state or school or neighborhood. Our "mindfulness" must also include them, their experience, their reality. 
This is what the liberation theologians mean by the "hermeneutical privilege of the poor." From their position of suffering and exploitation, the oppressed can see the world in ways that the powerful or the comfortable cannot. The mindfulness we practice on our cushions or in our pews must be balanced and expanded by the mindfulness gained on the streets.

If Christians remind Buddhists that personal transformation is incomplete without social transformation, Buddhists in turn will remind Christians that social transformation is impossible without personal transformation. For Buddhists, I believe, inner transformation of consciousness has a certain priority over social transformation.

One can carry out the task of being a bodhisattva only if one has experienced the wisdom that produces compassion. Prajna, or wisdom, is what one knows when one begins to wake up to the interconnectedness or the interbeing of all reality. Realizing that one's very being or self is not one's own but the being of all other selves, one will necessarily feel compassion for all sentient beings.

Buddhists are calling Christians to recognize (or reaffirm) the subtle, but real, primacy of contemplation over action and of compassion over justice.

\section{The primacy of contemplation over action}

There is a Buddhist conviction that we must undergo a profound personal transformation before we can "wisely" interact with the world around us. We are born into a fundamental ignorance that we must deal with before we can begin to truly know who and what we and the world really are. If we don't overcome this ignorance before fixing the world's problems, we're probably only going to cause more problems. Although Buddhists have much to learn from Christians about what kind of action must arise out of contemplation (that is, socially transformative action), Christians need to learn from Buddhists why action without contemplation is unsustainable and dangerous.

Buddhist contemplation aims at a nondual experience of our interbeing or reciprocal interdependence with what is ultimate (the nature of mind/ spirit). This is what establishes in us an inner peace; it is also what sustains us in working for the Reign of God. No matter what happens, no matter how much failure or opposition, if we are peace, we will continue to try to make peace (Hanh 1992). Such inner peace and groundedness is a protector or an antidote to the danger of burnout that threatens all social and peace activists. Working for peace and justice is hard, often frustrating, work.

\section{The primacy of compassion over justice}

But contemplation manifests its priority not only by sustaining action but also by guiding it. Thich Nhat Hanh challenges the Christian insistence on the "preferential option for the oppressed." God, he declares, doesn't have 
preferences. God - or Essence Love - embraces all beings - poor and rich, oppressed and oppressor - equally (Hanh 1995).

Christians remind Buddhists that compassion without justice - that is, without reform of structural injustice - is not enough to relieve suffering; Buddhists remind Christians that, just as there can be no peace without justice, there can also be no justice without compassion.

This Buddhist challenge reminds us of what Jesus himself taught. People will know who Jesus's disciples are not by their work for justice, but by their love for each other. Jesus's "first commandment" is love, not justice (Jn 13: 35). And Jesus called on us to love our enemies as much as we love our friends, which means loving the oppressor as much as we love the oppressed. This doesn't mean we will not confront our enemies and oppressors. But our primary motivation for doing so will not be the demand of justice, but the demand of love. We will confront oppressors with what Makransky calls "a fierce compassion" (Makransky 2014).

Thich Nhat Hanh, in his little book on Living Buddha, Living Christ, informs Christians that, for a Buddhist, God doesn't have favorites. He is thus reminding Christians that just as there is a relationship of nonduality between emptiness and form, or between Abba-Mystery and us, so there is a nonduality between oppressed and oppressor. Both are expressions of interbeing and Abba-Mystery. The actions of oppressor or oppressed are clearly different. But their identities are the same. And that means that my own identity is linked to both oppressed and oppressors.

Therefore, we do not respond to the oppressed out of compassion and to the oppressor out of justice. No, we respond to both out of compassion! Compassion for both the oppressed and the oppressor. So, yes, we want to liberate the oppressed. But just as much, we want to liberate the oppressors. Compassion for the oppressor will be expressed differently than compassion for the oppressed. But just as much, we want to free the oppressors from the illusions that drive them to greed and to the exploitation of others. Such a nonpreferential option for compassion that extends equally and clearly to both oppressed and oppressors will be the foundation on which justice can be built, on which structures can be changed.

Some kind of a spiritual practice that will foster and sustain our inner transformation and resources is imperative. To have begun the process of awakening to oneness with Christ and to what Jesus experienced as the unconditional love of the Abba-Mystery can assure us that our efforts are not just our own efforts. Once we begin to wake up to the wisdom that reveals to us that all our efforts are grounded in and expressions of the Abba-Mystery that is active in and as us, once we begin to realize that in working for peace and justice we are doing what our Christ-nature necessarily calls us to do - then we will also realize that, as the Bhagavad Gita tells us, the value of our actions are not determined by their fruits. The value of our actions is in our actions themselves, for they are also the actions of Abba. 
This deeper experience of the nonduality between the Abba-Mystery and the world, or between the future and the present Reign of God, assures Christians that even though their efforts to bring the world closer to the Reign of God fail, Abba and the Reign are still present and available. In both success and failure, the Reign of God is both already/not yet.

The Buddhist experience of "enlightenment," of waking up to what Mahayana Buddhists term our "Buddha-nature," is, I believe, a prompt for Christians to enter more profoundly into the unitive experience signaled in John's description of Jesus as "one with the Father" and "one with us" (Jn 14), or in Paul's description (I would dare say "definition") of a Christian as someone who exists "in Christ." I am suggesting that the nondual unity that Mahayana Buddhists affirm between emptiness and form, or between Nirvana and Samsara, or (in Thich Nhat Hanh's terminology) between interbeing and all finite beings, is analogous to, if not the same as, the unity between Jesus and Abba or between Christ and us. The divine and the finite, the creator and the created are, like emptiness and form, distinct but inseparable. They co-inhere. They "inter-are."

When we begin to "awaken" to our oneness with Christ in the Father, when we begin to feel that "it is no longer I who live but Christ who lives in me" (Gal 3:21), we are awakening to what Buddhists call prajna, or wisdom - the awareness of the fundamental, all pervasive interconnectedness of all reality. We are all truly "one in the Spirit." And this realization that we are interlinked in the Divine Mystery will naturally bring forth in us what Buddhists call karuna, compassion, for all our fellow human beings indeed, for all sentient beings. To love our neighbor is not a commandment; it is a natural necessity.

Here Buddhists are offering us Christians an opportunity to clarify, perhaps reform, our soteriology - our doctrine on how Jesus brings about "salvation." The cross can save a world wracked by the sufferings caused by greed and hatred and violence by embodying and making clear the power of nonviolent love. Jesus died on the cross not because the Father willed it, but because he refused, as the Dhammapada counsels, to answer hatred with hatred. Rather than answering the violence of the colonizing Romans and their local collaborators with his own violence, rather than abandoning his mission of proclaiming the Reign of God, he responded with love and trust, and, as the Latin American martyrs express it, he was "disappeared."

And the power of this embodiment of nonviolent love was such that, after he died, his followers, gathered around the table to break bread and remember him, realized that he was still with them. His example of love confronting hatred, of nonviolence responding to violence, transformed their lives with the power to go and do likewise. To be so transformed is to be redeemed and saved. His followers share in his "Christ-nature," just as the followers of Buddha continue to realize their "Buddha-nature." And by realizing my Buddha-nature, I have been able to understand and to live my Christ-nature. 


\section{Note}

1 This benefactor practice is laid out clearly and practically in Makransky's Awakening through Love (2007).

\section{References}

Haight, Roger, and Paul Knitter. 2015. Jesus and Buddha: Friends in Conversation. Maryknoll: Orbis Books. doi:10.1086/696274

Hanh, Thich N. 1992. Peace Is Every Step: The Path of Mindfulness in Everyday Life. New York: Bantam.

Hanh, Thich N. 1995. Living Buddha, Living Christ. New York: Riverhead Books.

Makransky, John. 2007. Awakening Through Love. Somerville, MA: Wisdom Publications.

Makransky, John. 2014. "A Buddhist Critique of, and Learning from, Christian Liberation Theology.” Theological Studies 75 (3): 635-657. doi:10.1177 /0040563914541028

Panikkar, Raimundo. 1979. "The Myth of Pluralism: The Tower of Babel - A Meditation on Non-Violence." CrossCurrents 29 (2): 197-230. 